\title{
Siderosis, haemolysis or hepatonecrosis in increasing post-desferrioxamine sideruria in acute viral hepatitis ?
}

\author{
L. A. SCURO \\ M.D.(Padua) \\ G. Dobrilla \\ M.D.(Padua) \\ Institute of Medical Pathology of the University of Padua, Padua, Italy
}

Post-desferrioxamine (DF) sideruria is accepted as a significant diagnostic test in dis-siderotic states: the highly marked iron excretion, observed in primary haemochromatosis, bears witness to this as does the quite low sideruria seen in irondeficient conditions.

Likewise, in acute viral hepatitis, an elevated urinary iron elimination following DF administration has been reported for more than 2 years (Schnack \& Wewalka, 1964 ; Dobrilla et al., 1966). In thirty-eight hepatitis patients Scuro et al. (1966) found post-DF sideruria values significantly increased in respect to the controls (Table 1). Quite

TABLE 1

Twenty-four-hour sideruria mean values following desferrioxamine ( $1 \mathrm{~g}$, intramuscularly)

\begin{tabular}{lcc}
\hline Groups & Mean values & \pm standard error \\
\hline $\begin{array}{c}\text { Normal controls } \\
\text { (30 cases) }\end{array}$ & $890.20 \pm 69.67$ \\
$\begin{array}{c}\text { Hepatitis patients } \\
\text { (38 cases) }\end{array}$ & $2,453.74 \pm 0264$ \\
Significance & $P<0.001$ \\
\hline
\end{tabular}

often the single values fell within a definitely pathological range $(6,8$ and, exceptionally, even $10 \mathrm{mg} / 24 \mathrm{hr}$ ) such as those usually found only in overt hypersiderotic situations. This elevated iron excretion can be erroneously evaluated if the factors which determine it are not considered. Indeed, in spite of frequently positive desferrioxamine tests, there is reason to believe that in the specific case of viral hepatitis such results do not express the existence of an actual hypersiderosis. In addition to the disputable hepatosiderosis two further explanations are feasible regarding the high post-DF sideruria in viral hepatitis: (1) that it is due to a concomitant haemolytic condition, and (2) that it is attributable to a release of iron (free or ferritin-Fe) in the blood by necrotic hepatocytes.

We would like to briefly discuss the abovementioned possibilities.

\section{Post-DF sideruria and hepatic siderosis}

Hult (1952) has reported the possibility of hepatic siderosis some time after the acute phase of the disease. During the acute period very few histochemical studies have been carried out on the presence of iron pigments in hepatic cells. The significance of such a study in acute hepatitis is underlined by the coexistence of hypersider. aemia and elevated post-DF urinary iron. Con. sequently, in fifty young hepatic patients without histories of haematological disorders, iron metabolic abnormalities and alcoholism, liver biopsies were made with Vim-Silverman needles in order to evaluate the iron content histochemically (Perls' method). Only in five patients, or some $10 \%$, was a positive Perls' reaction of grade I, according to the classification of Higginson et al. (1953), seen. Even considering the limitations relative to all biopsies, this finding seems to decidedly exclude the presence of hepatic siderosis in spite of the positive DF test. Our data agree with those of Schnack \& Wewalka (1965) who likewise found elevated sideraemia and post-DF iron elimination $(4000 \mu \mathrm{g} / 24 \mathrm{hr})$ values in acute hepatitis subjects. They, like ourselves, are of the opinion that 'this iron excretion is not correlated to an excessive iron storage in the liver, demonstrated histologically'.

\section{Post-DF sideruria and haemolysis}

It is now acknowledged that a more or less appreciable degree of haemolysis, clearly documented by a net reduction in the erythrocyte life span, is present in acute viral hepatitis (Pitcher \& Williams, 1963). It is thus quite reasonable to ask oneself whether the high post-DF excretion in this disease does not depend upon the lowered erythrocyte survival rate; Smith, Studley \& Williams (1967) are oriented in this direction. Indeed, it has been shown that under various anaemic conditions of an overtly haemolytic nature, the post-DF sideruria values may be very high, quite similar to those observed in hypersiderotic sub- 
jects (Fielding, 1965). Fielding explains this phenomenon by suggesting that DF is able to chelate the iron which originates from haemoglobin catabolism.

In confirmation of this, O'Shaughnessy, Brunström \& Fielding (1966) report that in traumatized subjects having haematomas DF provokes a marked urinary iron elimination, so precocious that it cannot be explained by an increase in the storage iron proteins, but only by a DF chelation of intermediates derived from haemoglobin degradation. More recently, Fielding (1967) cites, in support of his opinion, the results of Cumming et al. (1967) who were able to increase the postDF sideruria by inducing haemolysis with phenylhydrazine in both rian and animal.

Fielding's interpretation appears interesting: desferrioxamine B, capable of removing iron from complex molecules such as ferritin and haemosiderin, should be able to chelate the iron resulting from haemoglobin catabolism to a greater extent, since in this dynamic metabolic phase iron has yet to acquire stable and complex bonds. Nevertheless, in agreement with Ventura (1967), other considerations and other data must be taken into account before accepting this hypothesis without reserve.

First of all, during protracted $\mathrm{D} F$ administration, whatever the iron deposition, and, consequently, the iron elimination may be, one observes an always variable and progressively decreasing sideruria. This decrease, at times highly marked, should not occur if the DF chelates the iron from the haemoglobin pool, which, in man, is approximately $23-25 \mathrm{mg} / 24 \mathrm{hr}$.

Secondly, if this iron, liberated daily by the erythrocytes and daily recycled via plasma to the bone marrow for $\mathrm{Hb}$ synthesis, could be chelated by desferrioxamine, in DF treatment protracted over an extended period we should observe some degree of anaemia which even in therapeutic courses of more than a year's duration has never been reported.

Thirdly, if the hyperhaemolytic situations are accompanied, not by ineffective, but by vigorous compensatory erythropoiesis, the post-DF sideruria falls within the normal range (Ventura, 1967).

Fourthly, in the case of thalassaemia major where the haemolysis is of indisputable gravity, one observes abnormal post-DF sideruria only if numerous transfusions have been given (some 15-16 $\mathrm{g}$ of $\mathrm{Fe}$ ), while one notes a urinary iron excretion significantly lower, if the transfused iron is less (approximately $8 \mathrm{~g}$ ) (McDonald, 1966). This attributes a preeminent importance to the iron deposits in the haemolytic situation.
Lastly, the experiments of Cumming et al. (1967) have shown that the administration of phenylhydrazine increases DF-induced iron excretion in patients affected with haemochromatosis, but this occurs only in previously non-phlebotomized patieri.s. In those previously treated by venesection, the administration of phenylhydrazine does not significantly increase the post-DF sideruria. In addition they observed the same phenomenon in a patient affected with sideroblastic anaemia and in one with idiopathic pulmonary haemosiderosis. This observation is very important as it shows that, even though phenylhydrazine always causes haemolysis, this latter does not necessarily, or directly, increase the post-DF sideruria per se. Cumming and co-workers, in order to explain this discrepancy, form the hypothesis that the haemolysis, stimulating the erythropoietic response, favours the mobilization of $\mathrm{Fe}$ from the deposits either as free iron or as ferritin. According to the same authors this mobilization would not take place in pulmonary haemosiderosis because the iron deposits in the lungs would not be readily removable.

\section{Post-DF sideruria and hepatonecrosis}

In order to understand the pathogenesis of elevated post-DF sideruria in acute viral hepatitis, it is necessary to consider the reason for hypersideraemia in this disease. Several previous explanations such as a lowered biliary excretion, a block in the storing of iron in the damaged liver, and a decreased utilization of iron in $\mathrm{Hb}$ synthesis can be excluded. The concomitant haemolytic factor and the necrosis of the hepatic cells remain to be considered as the ultimate cause. It seems reasonable to assume that, whenever haemolysis exists in acute viral hepatitis, it could influence the sideraemic values. Nevertheless, only in the case of a haemolysis much more marked than that usually seen in acute hepatitis, are sideraemic values of the order of those observed in this disease found. Even considering haemolysis as a possible additional cause of hypersideraemia, we hold that the hepatonecrosis, without doubt the most relevant pathological event, has a much greater pathogenetic significance. Studies on experimental hepatonecrosis fully confirm a causal interrelationship between it and the increase in serum iron values, even if a perfect parallelism between the two does not always exist. According to Robalo Cordeiro et al. (1966) the liberation of $\mathrm{Fe}$ from the damaged liver would take place in two ways: a rapid liberation from the necrotic cells of the $\mathrm{Fe}$-apoferritin complex and a slow liberation from the damaged, but not yet necrotic, cells of ionic iron, cleaved from ferritin. The studies of Reissmann \& Dietrich 
(1956) are conclusive in that they have directly shown the existence of ferritin in the blood of hepatitis patients by an immunological procedure.

Can this peculiar increase in serum Fe explain the high post-DF sideruria? Several considerations and various experimental data seem to confirm this. It is in fact known that ferritin is the iron-protein which is most readily chelated by desferrioxamine. The removal of the metal from haemosiderin is indeed slower, while the DFchelation from transferrin is with certainty demonstrated only in vitro. In acute viral hepatitis in which circulating ferritin is present, conditions are most favourable for desferrioxamine to exert its chelating action in the blood itself. If this assumption is true, in this disease the elevated post-DF sideruria should be associated with a decrease in the serum iron levels.

Our studies (Scuro et al., 1966, 1967) fully confirm this hypothesis (Fig. 1). In the first $6 \mathrm{hr}$

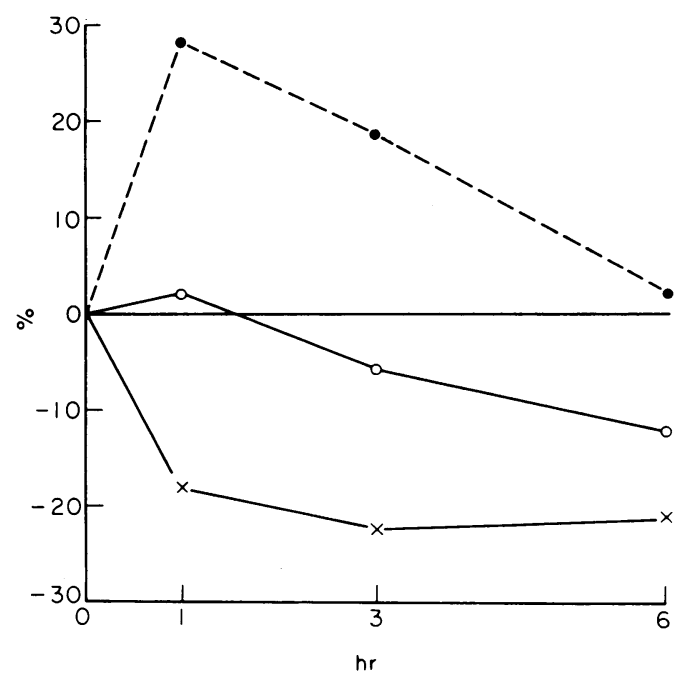

FIG. 1. Average per cent variations of sideraemia after DF administration (1 $\mathrm{g}$ intramuscularly). Haemochromatosis; $O$, normal controls; $x$, acute viral hepatitis.

\begin{tabular}{llll}
\hline & $1 \mathrm{hr}$ & $3 \mathrm{hr}$ & $6 \mathrm{hr}$ \\
\hline $\begin{array}{l}\text { Normal controls } \\
\quad(10 \text { cases })\end{array}$ & +2.3 & $-5 \cdot 5$ & $-12 \cdot 1$ \\
$\begin{array}{l}\text { Haemochromatosis } \\
\quad(16 \text { cases) }\end{array}$ & +28.5 & $+18 \cdot 4$ & $+2 \cdot 4$ \\
$\begin{array}{l}\text { Acute viral hepatitis } \\
(29 \text { cases) }\end{array}$ & -18 & $-22 \cdot 3$ & $-21 \cdot 1$ \\
\hline
\end{tabular}

following DF administration, when the urinary iron excretion is at its highest, the most conspicuous sideraemic variations are also observed. This is almost the exact opposite of that seen in haemochromatosis, following DF administration, in which the hypersideraemia actually expresses the increased iron reserves. It is of importance to point out that Cumming (personal communication 1967), in explaining the increase in post-DF sideruria values induced by haemolysis, formulates the hypothesis 'that the stimulus to erythropoiesis may cause an increase in plasma ferritin'. Thus, in viral hepatitis there would be two reasons for ferritinaemia: the first, an acute necrosis of the hepatic cells, and, the second, an accompanying haemolysis. Without doubt it would be worthwhile to examine not only the sideruria, but also any eventual post-DF sideraemic variations in the clearly haemolytic patients. Our relatively few observations do not yet permit us to formulate definite conclusions.

To summarize it seems reasonable to hold that in acute viral hepatitis the pathogenetic factors of hypersideraemia can explain the peculiar behaviour of post-DF sideruria. In fact, desferrioxamine can chelate the iron (ionic Fe, ferritin) freed from the necrotic hepatic cells in the blood itself. This greatly facilitates the iron chelation process and, consequently, that of the urinary iron excretion.

Also haemolysis, present to a more or less marked extent, can to a certain degree influence the DF test. This influence seems to manifest itself in an indirect manner since it has been seen that it is insufficient per se to always provoke an elevated urinary iron excretion. Nevertheless, it remains, in our opinion, a less important factor in respect to that represented by hepatonecrosis.

Finally, we hold that the elevated post-DF sideruria in acute viral hepatitis does not depend upon liver siderosis, a picture excluded by morphological studies. The results of the DF test in the hepatitis subject, which would suggest an iron overload condition, must then be considered 'false positive'.

\section{References}

Cumming, R.L.C., Goldberg, A., Morrow, J. \& Smith, J.A. (1967) Effect of phenylhydrazine-induced haemolysis on the urinary excretion of iron after desferrioxamine. Lancet, i, 72.

Dobrilla, G., Lechi, A., Innecco, A., Mazzucato, P. \& Scuro, L.A. (1966) Rilievi intorno al metabolismo del ferro nell'epatite virale umana. L'impiego del test della desferrioxamina. G. Mal infett. 18, 551.

FieldiNG, J. (1965) Differential ferrioxamine test for measuring chelatable body iron. J. clin. Path. 18, 88.

FielDiNG, J. (1967) Iron excretion after desferrioxamine. Lancet, i, 329.

Higginson, J., Gerritsen, T. \& Walker, A.R.P. (1953) Siderosis in the Bantu of Southern Africa. Amer. J. Path. 29, 779.

Hult, H. (1952) Posthepatitic siderosis of the liver. Acta med. scand. 142, 113. 
MCDonald, R. (1966) Deferoxamine and diethylentriaminepentacetic acid (DTPA) in thalassemia. J. Pediat. 69, 563.

O’Shaughnessy, M.C., Brunström, G.M. \& Fielding, J. (1966) Iron chelation in haematomas at fracture sites. J. clin. Path. 19, 364.

Pitcher, C.S. \& Williams, R. (1963) Reduced red cell survival in jaundice and its relation to abnormal glutathione metabolism. Clin. Sci. 24, 239.

ReissmanN, K.R. \& Dietrich, M.R. (1956) On the presence of ferritin in the peripheral blood of patients with hepatocellular disease. J. clin. Invest. 55, 588.

Robalo Cordeiro, A.J.A., Trincao, R.C.A., Breda Coimbra, H.L., Mesquita, A., Proenca, M.S.F., Severo, F.R.C. \& Almeida, J.C.C. (1966) Le foie dans la physiopathologie du fer. I. Circulation plasmatique du fer (cirrhose et nécrose hépatiques). $R$. I. H. 16, 6 .

Schnack, H. \& Wewalka, F. (1964) Ergebnisse eines tests zum Nachweis vermehrter Eisenspeicherung im Organismus bei Leberkrankheiten. Verh. dt. Ges. inn. Med. $70^{\circ}$ Congress, 1964, p. 411.

Schnack, H. \& Wewalka, F. (1965) Chronic liver disease and iron storage in the liver. Advances in Hepatology (Ed. by J. Vandenbroucke, J. De Groote and L. O. Standaert), p. 342. Basle.

Scuro, L.A., Dobrilla, G., InNecco, A., Lechi, A., MonTI, G. \& OKolicsanyi, L. (1966) Indagini istochimiche e funzionali intorno alla genesi della ipersideremia nell'epatite virale acuta. Policlinico, 73, 73.

Scuro, L.A., Dobrilla, G., Lechi, A., Innecco, A. \& Cavallini, G. (1967) Twenty-four hour desferrioxamine test in normal iron deficient and hypersideraemic (both hypersiderotic and not hypersiderotic) subjects. Panminerva (In press).

Smith, P.M., Studley, F. \& Williams, R. (1967) Assessment of body-iron stores in cirrhosis and haemochromatosis with the differential ferrioxamine test. Lancet, i, 133.

Ventura, S. (1967) Il comportamento della desferroxamina B nell'organismo umano. Atti Giornate Ematologiche Napoletane 1965 (In press). 